\title{
Renal coccidiosis in the European cormorant Phalacrocorax aristotelis aristotelis from the Galician coast
}

\author{
Elvira Abollo* ${ }^{\dagger}$ and Santiago Pascual ${ }^{\dagger}$ \\ * Centro de Investigacións Mariñas, Consellería de Pesca e Asuntos Marítimos, Marisqueo e Acuicultura, Aptdo. 13, \\ E-36620 Vilanova de Arousa, Spain. '†nstituto de Investigaciones Marinas (CSIC), Eduardo Cabello 6, 36208 Vigo, Spain. \\ †Corresponding author, e-mail: eabollo@cimacoron.org
}

\begin{abstract}
A developmental stage of a species of eimeriorin Apicomplexa was found heavily infecting the kidney of the European cormorant Phalacrocorax aristotelis aristotelis beached on the coast of Galicia after the oil spill from the 'Prestige'. The immature condition of the parasite made a precise taxonomic identification impossible. The infection caused kidney damage as a result of pressure atrophy and mechanical displacement exerted by oocysts which occupied large areas of host tissue. A cellular host reaction was always apparent in the kidney of the infected cormorants. Although the oil effect is assumed to be responsible for the death of the cormorants, the impact of the coccidiosis should be monitored in the European shag populations.
\end{abstract}

\section{INTRODUCTION}

The world population of the Atlantic subspecies of cormorant, Phalacrocorax aristotelis aristotelis (Linnaeus, 1758) is between 70,000 and 90,000 pairs. This subspecies is the most meridional in its distribution, with an estimated population of about 2220-2300 pairs in Iberian Peninsula waters (Velando et al., 1995). In the Galician coast, Velando et al. (1995) recorded 86\% of the European cormorant from the Atlanto-Iberian Peninsula waters.

Coccidiosis is probably the most important parasitic disease of veterinary importance throughout the world (Cox, 1998). Of the few coccidians reported from coastal birds most appear to be non-pathogenic, although in its acute form coccidiosis can be a fatal avian disease (Gregory, 1990). The present paper reports the occurrence of a renal coccidian and its associated pathology in the European shags that died after the oil spill from the 'Prestige' which occurred off the Galician coast.

\section{MATERIALS AND METHODS}

A total of 32 oiled-cormorants, Phalacrocorax aristotelis aristotelis, beached on the coast of Galicia during the oil spill from the 'Prestige', were examined for parasites during December 2002 and February 2003. Fresh squash preparations of infected kidney were observed by light microscopy. A total of 25 oocysts from different host individuals were measured using a calibrated ocular micrometer. Portions of infected kidneys were also fixed in 10\% formalin for $24 \mathrm{~h}$ and then processed by standard techniques for histopathological evaluation (Culling et al., 1985). The tissues were stained with haematoxylin-eosin $(\mathrm{H} \& \mathrm{E})$ and Wheatley's trichrome. Unsporulated oocysts were recovered and isolated from the host tissue as described by Abollo et al. (2001) to stimulate oocyst sporulation. Pools of coccidian oocysts were then placed in antibiotic solutions in saline or water, or mixed with $2.5 \%$ aqueous potassium dichromate solution and placed in a Petri dish at room temperature for different periods of time (5-30 days).

\section{RESULTS}

During necropsy no external macroscopic lesions were observed in the kidneys of oiled-cormorants. Fresh squash examinations from nine host individuals revealed numerous unsporulated ellipsoidal oocysts (prevalence $28.12 \% \pm 17.32$ ). Oocysts measured $19.35 \mu \mathrm{m} \times 16.05 \mu \mathrm{m}$ (ranging from 18.12-21.41 $\mu \mathrm{m} \times 13.72-17.57 \mu \mathrm{m}$ ), length/ width $(\mathrm{L} / \mathrm{W})$ ratio $1.20(1.06 / 1.56)$ (Figure 1). In fresh squash preparations and histological sections young and older oocysts showed a thin hyaline wall, finely cytoplasmatic granules and a large centrally located nucleus. The oocyst wall was smooth and colourless. Young unsporulated oocysts showed all the space within the oocyst wall filled by cytoplasm, whereas the older unsporulated oocysts were protoplasm condensated. Between the oocyst boundary and the external wall a membranous envelope was apparent. Despite various attempts to obtain sporulated oocysts, the sporulation assay was always unsuccessful.

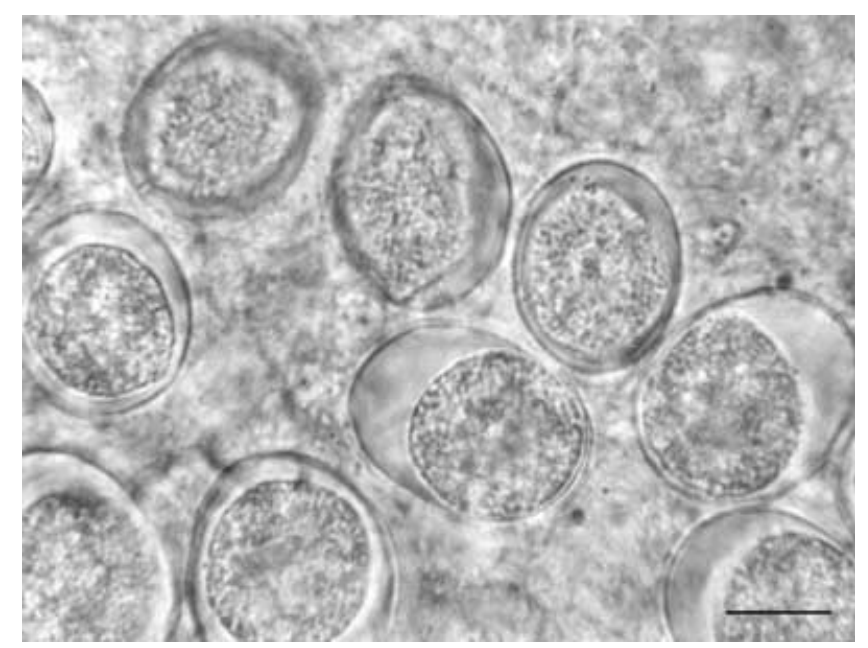

Figure 1. Fresh mount of unsporulated oocysts. Scale bar: $10 \mu \mathrm{m}$. 

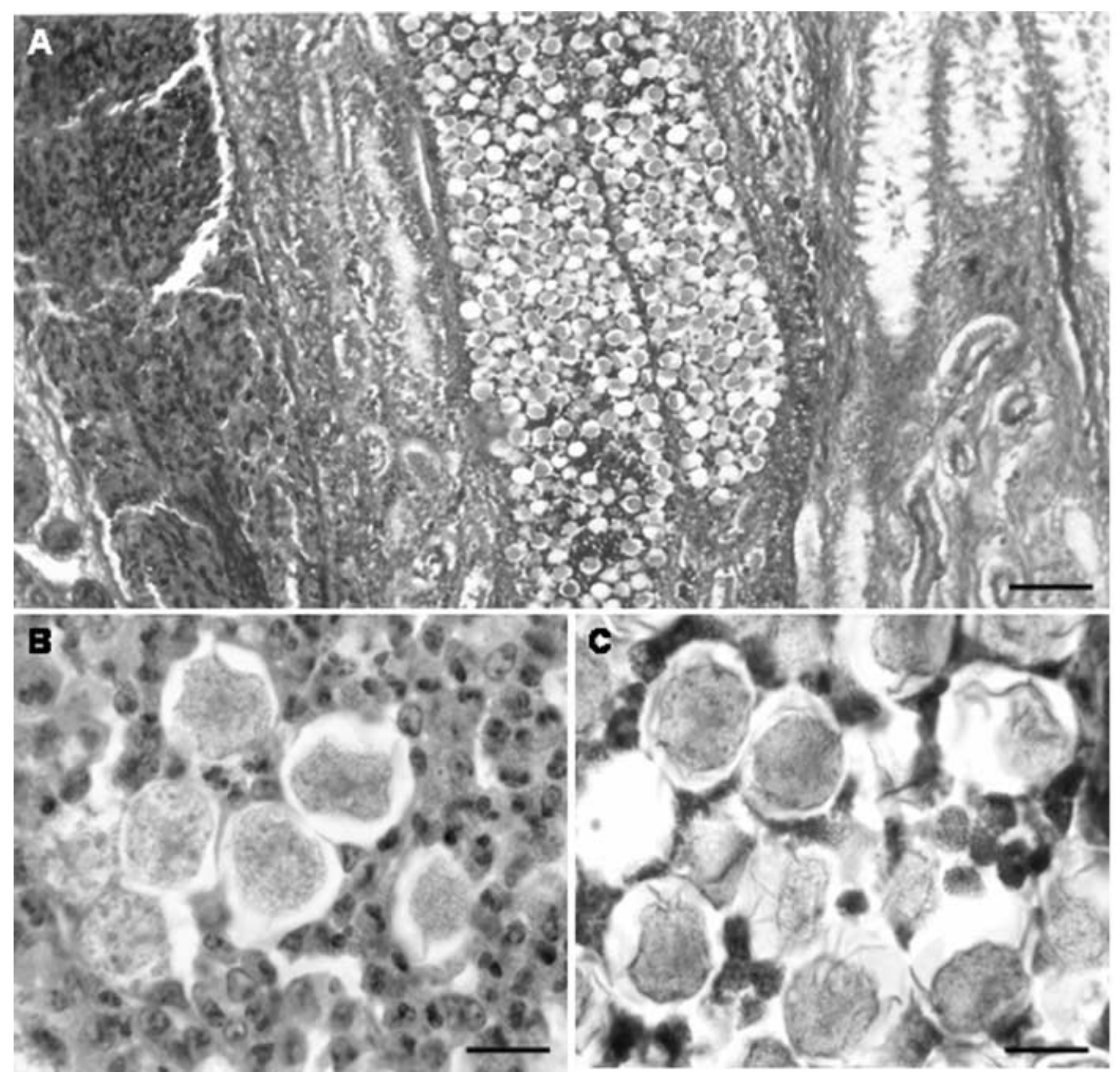

Figure 2. Infected kidney of Phalacrocorax aristotelis. Histological sections showing (A) extensive tissue damage and haemorrhagic areas; (B) inflammatory reaction in response to infection; $(\mathrm{C})$ phagocytic cells surrounding the oocysts. Scale bars: A, $100 \mu \mathrm{m}$; B,C, $10 \mu \mathrm{m}$.

The oocysts made up a large part of the heavily dilated renal tubules, causing mechanical displacement of host tissue. All kidney tissue was affected, being partially or completely destroyed by the protozoan and showing distension and necrosis of the renal tubules. Oocysts were not contained in large nodules or surrounded by fibrous capsule. The tissue also showed a generalized haemorrhage apparently not associated with the renal coccidiosis (Figure 2A). Host response to the coccidian parasite was observed as an inflammatory reaction (Figure 2B). Eosinophils, macrophages and lymphocytes were found infiltrating the tissue as part of the process of chronic inflammation. Phagocytic cells were observed adhering to and surrounding the oocysts (Figure 2C). In some areas reparative process of the local tissues was observed, with proliferating fibroblasts, which gradually repaired the damaged area, but showed little evidence of organization.

\section{DISCUSSION}

Commonly avian coccidian infections are diagnosed by faecal examination for the presence of oocysts, which must sporulate before the taxonomic characters become apparent. The taxonomic status of the renal eimeriid found in the present work is unknown, because the sporulation experiments, necessary for verifying the identity of the genus, were unsuccessful. Nevertheless, some taxonomic features of diagnostic value (i.e. the thick wall, finely cytoplasmatic granules, large centrally located nucleus and the absence of a prominent nucleolus) allowed us to identify the material as oocyst stages of an eimeriorin. To date two species of Eimeria have been described from the intestine of Phalacrocorax (Labbé, 1893; Hoare, 1933) and only a single species, E. auritus, parasitizing the kidney of Phalacrocorax auritus (Yabsley et al., 2002). However, as the location, form and size of the oocysts herein reported does not fit previous descriptions for coccidians already reported from the Phalacrocoridae, it is possible that this species has not yet been described.

In the sampled oiled cormorant the histopathological examination of the coccidian infections provided clear evidences of their pathogenicity. It is generally assumed that under natural conditions Coccidia cause little disease unless the host-parasite balance is upset. The oil spill from 
the 'Prestige' was the cause of death. Nevertheless, the pathogenicity of coccidiosis in the well-being of the infected cormorant populations stressed by xenobiotics should be further monitored because of the parasite impact on renal tissue architecture contributing to avian mortality.

This work is dedicated to the human 'white tide' working in the Galician coast after the 'Prestige' oil tanker wreckage of tons of crude oil in November 2002.

\section{REFERENCES}

Abollo, E., Calvo, M. \& Pascual, S., 2001. Hepatic coccidiosis of the blue whiting, Micromesistius poutassou (Risso), and horse mackerel, Trachurus trachurus (L.), from Galician waters. Fournal of Fish Diseases, 24, 335-343.

Cox, F.E.G., 1998. Control of coccidiosis: lesson from other sporozoa. International fournal for Parasitology, 28, 165-179.
Culling, G.F.A., Allison, R.T. \& Barr, W.T., 1985. Cellular pathology technique, 4th edn. London: Butterworth.

Gregory, R.D., 1990. Pathology of coccidial infections. In Coccidiosis of man and domestic animals (ed. P.L. Long), pp. 235261. Florida: CRC Press.

Hoare, C.A., 1933. Studies on some new ophidian and avian coccidia from Uganda, with a revision of the classification of the Eimeriidae. Parasitology, 24, 359-388.

Labbé, A., 1893. Sur les coccidies des oiseaux. Comptes Rendus Hebdomaires des Séances de l'Académie des Sciences, 117, 407-409. [In French.]

Velando, A., Ortega-Ruano, J.E. \& Docampo, F., 1995. La población de cormorán moñudo en el Atlántico ibérico. Quercus, 116, 16-22. [In Spanish.]

Yabsley M.J., Gottdenker N.L. \& Fischer, J.R., 2002. Description of a new Eimeria sp. and associated lesions in the kidneys of double-crested cormorants (Phalacrocorax auritus). Fournal of Parasitology, 88, 1230-1233.

Submitted 24 March 2004. Accepted 2 December 2004. 